\title{
Serum- and glucocorticoid-inducible kinase 1 and the response to cell stress
}

\author{
Florian Lang ${ }^{1, *}$, Christos Stournaras ${ }^{2}$, Nefeli Zacharopoulou'2, Jakob Voelk ${ }^{3,4}$, loana Alesutan ${ }^{3,4,5}$ \\ ${ }^{1}$ Department of Vegetative and Clinical Physiology, Eberhard-Karls-University, Tübingen, Germany. \\ ${ }^{2}$ Department of Biochemistry, University of Crete Medical School, Voutes, Heraklion, Greece- \\ ${ }^{3}$ Department of Internal Medicine and Cardiology, Charité - Universitätsmedizin Berlin, Germany. \\ ${ }^{4}$ DZHK (German Centre for Cardiovascular Research), partner site Berlin, Germany. \\ ${ }^{5}$ Berlin Institute of Health (BIH), Berlin, Germany. \\ * Corresponding Author: \\ Florian Lang, MD, Department of Physiology, University of Tübingen, Wilhelmstr. 56, 72076 Tübingen, Germany; Phone $+49-707129$ \\ 72194; Fax: +49-7071 29 5618; E-mail: florian.lang@uni-tuebingen.de
}

\begin{abstract}
Expression of the serum- and glucocorticoid-inducible kinase 1 (SGK1) is up-regulated by several types of cell stress, such as ischemia, radiation and hyperosmotic shock. The SGK1 protein is activated by a signaling cascade involving phosphatidylinositide-3-kinase (PI3K), 3-phosphoinositidedependent kinase 1 (PDK1) and mammalian target of rapamycin (mTOR). SGK1 up-regulates $\mathrm{Na}^{+} / \mathrm{K}^{+}$-ATPase, a variety of carriers including $\mathrm{Na}^{+}-, \mathrm{K}^{+}-, 2 \mathrm{Cl}-$ cotransporter (NKCC), $\mathrm{NaCl}$ cotransporter (NCC), $\mathrm{Na}^{+} / \mathrm{H}^{+}$exchangers, diverse amino acid transporters and several glucose carriers such as $\mathrm{Na}^{+}$-coupled glucose transporter SGLT1. SGK1 further up-regulates a large number of ion channels including epithelial $\mathrm{Na}^{+}$channel $\mathrm{ENaC}$, voltage-gated $\mathrm{Na}^{+}$channel SCN5A, $\mathrm{Ca}^{2+}$ release-activated $\mathrm{Ca}^{2+}$ channel (ORAI1) with its stimulator STIM1, epithelial $\mathrm{Ca}^{2+}$ channels TRPV5 and TRPV6 and diverse $\mathrm{K}^{+}$channels. Furthermore, SGK1 influences transcription factors such as nuclear factor kappa-B (NF-KB), p53 tumor suppressor protein, cAMP responsive element-binding protein (CREB), activator protein-1 (AP-1) and forkhead box 03 protein (FOXO3a). Thus, SGK1 supports cellular glucose uptake and glycolysis, angiogenesis, cell survival, cell migration, and wound healing. Presumably as last line of defense against tissue injury, SGK1 fosters tissue fibrosis and tissue calcification replacing energy consuming cells.
\end{abstract}

doi: $10.15698 /$ cst2019.01.170

Received originally: 08.06 .2018 in revised form: 15.10.2018,

Accepted 17.10.2018,

Published 02.12.2018.

Keywords: SGK1, glycolysis, cell survival, cell migration, angiogenesis, fibrosis and tissue calcification.

\section{Abbreviations:}

mTOR - mammalian target of rapamycin

NF-KB- nuclear factor-kappa B, SGK1 - serum- and glucocorticoidinducible kinase 1 ,

TGF - transforming growth factor beta,

VSMC - vascular smooth muscle cell.

\section{INTRODUCTION}

The ubiquitously expressed [1-4] serum- and glucocorticoid-inducible kinase 1 (SGK1) has originally been cloned as a gene up-regulated by serum and glucocorticoids in rat mammary tumor cells $[1,5]$. The human SGK1 has been identified as a gene up-regulated by cell shrinkage [6].

\section{SGK1 expression}

Expression of SGK1 is highly variable and subject to regulation by a wide variety of triggers including hyperosmotic or isotonic cell shrinkage, dehydration, excessive glucose concentrations, mechanical stress, oxidative stress, heat shock, radiation, DNA damage, ischemia, neuronal injury and neuronal excitation [1, 3, 7-12]. SGK1 transcription is further up-regulated by several hormones and mediators including glucocorticoids, mineralocorticoids, gonadotropins, gestagens, $1,25(\mathrm{OH})_{2} \mathrm{D}_{3}$, erythropoietin, morphine, transforming growth factor $\beta$ (TGF $\beta$ ), interleukin-6, fibroblast and platelet-derived growth factor, thrombin, endothelin, advanced glycation end products (AGEs) and activation of peroxisome proliferator-activated receptor $\gamma$ (PPAR $\gamma$ ) [1]. Inhibitors of SGK1 expression include serum starvation, heparin, dietary iron, nucleosides and nephrilin [1]. Overall, SGK1 expression declines with age [13].

Signaling of transcriptional SGK1 regulation involves cytosolic $\mathrm{Ca}^{2+}$, cyclic AMP, stress-activated protein kinase-2 (SAPK2 or p38 MAPK kinase), protein kinase C (PKC), protein kinase RAF, big mitogen-activated protein kinase 1 (BMK1, also known as extracellular signal-regulated kinase 
ERK5), extracellular signal-regulated kinase 1/2 (ERK1/2), phosphatidylinositide-3-kinase (PI3K), reactive oxygen species, NADPH oxidases, nitric oxide and EWS/NOR1 (NR4A3) fusion protein [1].

The SGK1 promoter binds receptors for glucocorticoids (GR), mineralocorticoids (MR), progesterone (PR), $1,25(\mathrm{OH})_{2} \mathrm{D}_{3}(\mathrm{VDR})$, retinoids (RXR), farnesoids (FXR), sterol regulatory element-binding protein (SREBP), PPARY, CAMP response element-binding protein (CREB), p53 tumor suppressor protein, Sp1 transcription factor, activator protein 1 (AP-1), activating transcription factor 6 (ATF6), heat shock factor (HSF), reticuloendotheliosis viral oncogene homolog (c-Rel), nuclear factor kappa- B (NF-kB), signal transducers and activators of transcription (STAT), TGF $\beta$ dependent transcription factors SMAD3 and SMAD4, forkhead activin signal transducer (FAST) and the transcription factor TonE binding protein (TonEBP or NFAT5) [1].

SGK1 translation is stimulated by PI3K and requires actin polymerization [14].

\section{SGK1 activation and its degradation}

Once expressed SGK1 requires activation. Stimulators of SGK1 activity include insulin, IGF1, hepatic growth factor (HGF), follicle stimulating hormone (FSH), thrombin and corticosterone [1]. Signaling involving activation of SGK1 includes PI3K and 3-phosphoinositide (PIP3)-dependent kinase PDK1 [6]. Interaction of SGK1 and PDK1 is supported by the scaffold protein $\mathrm{Na}^{+} / \mathrm{H}^{+}$exchanger regulating factor 2 (NHERF2) [3]. PIP3 is degraded and activation of SGK1 thus suppressed by the phosphatase and tensin homolog PTEN [3]. SGK1 activation further involves WNK1 (lysine deficient protein kinase 1) and mammalian target of rapamycin mTOR complex-2 (mTORC2) composed of mTOR, Rictor (rapamycin-insensitive companion of mTOR), Sin1 (stress-activated protein kinase-interacting protein 1), mLST8 and Protor-1 [1, 15-27]. SGK1 is further upregulated by $\mathrm{p} 38 \alpha$ MAPK, ERK5, CAMP, lithium, $\mathrm{Ca}^{2+}$ sensitive calmodulin-dependent protein kinase kinase (CaMKK), G-protein Rac1, neuronal depolarization, oxidation, hypertonicity, and fibronectin $[1,3,6,28]$.

SGK1 degradation is triggered by ubiquitination involving NEDD4-2 (neuronal precursor cells expressed developmentally down-regulated) [1, 3] and Rictor/Cullin-1 [1, 2931]. SGK1 degradation is inhibited by glucocorticoidinduced leucine zipper protein-1 (GILZ) [32].

\section{SGK1 kinase targets}

The optimal consensus sequences for phosphorylation by SGK1 are R-X-R-X-X-(S/T)-phi and R-R-X-S/T (X = any amino acid, $R=$ arginine, $S=$ serine, $T=$ threonine, phi = hydrophobic amino acid) [3, 33]. Specific SGK1 targets are N-myc down-regulated genes NDRG1 and NDRG2 $[1,3]$. Other SGK1 targets are shared by other kinases including SGK and protein kinase B (PKB/Akt) isoforms [3].

SGK1 influences a variety of enzymes including ubiquitin ligase NEDD4-2, inducible nitric oxide synthase iNOS, phosphomannose mutase 2 (PMM2), phosphatidylinositol3-phosphate-5-kinase (PIKfyve), serine/threonine kinase WNK4, ERK2 (MAPK1), mitogen-activated protein ki-
nase/ERK kinase kinase 3 (MEKK3), stress-activated kinase (SEK1), B-Raf kinase, glycogen synthase kinase 3 (GSK-3), p53-ubiquitinating MDM2 and Notch1-IC protein degradating Fbw7 [1].

SGK1 up-regulates transcription factors such as CREB, AP-1 and NF-KB [1, 34-37]. On the other hand, SGK1 phosphorylates and thus activates NDRG1, which in turn downregulates NF-KB signaling $[1,38]$. Moreover, SGK1 downregulates transcription factor $\mathrm{p} 53$ and forkhead box $\mathrm{O} 3$ protein (FOXO3a) $[1,39,40]$.

SGK1 is a powerful regulator of several ion channels [1, $3,41]$, including epithelial $\mathrm{Na}^{+}$channel $\mathrm{ENaC}$, voltage-gated $\mathrm{Na}^{+}$channel SCN5A, renal outer medullary $\mathrm{K}^{+}$channel ROMK1, voltage-gated $\mathrm{K}^{+}$channels KCNE1/KCNQ1, KCNQ4, $\mathrm{Kv1.3,} \mathrm{Kv1.5,} \mathrm{Kv7.2/3,} \mathrm{Kv4.3} \mathrm{and} \mathrm{hERG,} \mathrm{the} \mathrm{Ca}^{2+}$ releaseactivated $\mathrm{Ca}^{2+}$ channel ORAI1 and its stimulator STIM1, transient receptor potential channels TRPV4, TRPV5 and TRPV6, kainate receptor GluR6, unselective cation channel 4F2/LAT, $\mathrm{Cl}^{-}$channels ClCka/barttin, ClC2, CFTR (Cystic fibrosis transmembrane conductance regulator) and VSOAC (volume-sensitive osmolyte and anion channel) as well as acid-sensing ion channel ASIC1 [1, 3].

SGK1 stimulates diverse carriers including $\mathrm{Na}^{+}-, \mathrm{K}^{+}-, 2 \mathrm{Cl}^{-}$cotransporter NKCC2, NaCl cotransporter NCC, $\mathrm{Na}^{+} / \mathrm{H}^{+}$exchangers NHE1 and NHE3, glucose carriers SGLT1, GLUT1 and GLUT4, amino acid transporters ASCT2, SN1, B(0)AT1, EAAT1, EAAT2, EAAT3, EAAT4 and EAAT5, peptide transporters PepT, $\mathrm{Na}^{+}$,dicarboxylate cotransporter $\mathrm{NaDC}-1$, creatine transporter $\mathrm{CreaT}, \mathrm{Na}^{+}$,myoinositol cotransporter SMIT as well as phosphate carriers NaPilla and NaPillb [1, 3]. Furthermore, SGK1 up-regulates the $\mathrm{Na}^{+} / \mathrm{K}^{+}$-ATPase and albumin uptake $[1,3]$.

Further targets of SGK1 include nephrin, type A natriuretic peptide receptor (NPR-A), $\mathrm{Ca}^{2+}$-regulated heat-stable protein of apparent molecular mass $24 \mathrm{kDa}$ (CRHSP24), the adaptor precursor (APP) Fe65, NDRG1 and NDRG2, myosinVc, filamin C, microtubule-associated protein tau, Cyclindependent kinase inhibitor $1 \mathrm{~B}\left(p 27^{\mathrm{Kip} 1}\right)$, and huntingtin [1, $3,40,42-44]$.

The present review discusses the role of SGK1 in the orchestration of cellular response to stress such as energy depletion. The case is made that SGK1 supports cellular energy supply by stimulation of glucose uptake and glycolysis, as well as by stimulation of angiogenesis. SGK1 supports cell survival and cell migration, a prerequisite of tissue repair. As last line of defense, SGK1 replaces energy consuming cells with extracellular matrix by stimulation of tissue fibrosis and tissue calcification. In order to limit the number of citations some of the earlier original papers have been replaced by reviews.

\section{GLUCOSE UPTAKE AND GLYCOLYSIS}

SGK1 stimulates cellular glucose uptake and thus enhances the availability of glucose for glycolysis [3]. SGK1 further stimulates the $\mathrm{Na}^{+} / \mathrm{H}^{+}$ion exchanger [36] which generates an alkaline cytosolic $\mathrm{pH}$, a prerequisite for an increase of glycolytic flux [1]. The up-regulation of SGK1 in ischemia thus supports energy supply by glycolysis $[2,3,10,45]$. 


\section{ANGIOGENESIS}

SGK1 is required for angiogenesis during embryonic development [46] and following ischemia in the adult [47]. In myocardial ischemia, lack of SGK1 blunts the phosphorylation of SGK1 target protein NDRG1 and compromises the up-regulation of transcription factor NF-KB and its target protein, VEGF-A (vascular endothelial growth factor A). Lack of SGK1 further impairs endothelial cell (ECS) migration and tube formation in vitro, and decreases in vivo angiogenesis after myocardial infarction [47].

\section{CELL SURVIVAL}

SGK1 supports cell survival and cell proliferation of both tumor cells and neurons $[1,3,7,10,48-52]$. SGK1 is highly expressed in several tumors [10], including non-small cell lung cancer [53], colon cancer [10], prostate cancer [54], ovarian tumors [1], myeloma [55], and medulloblastoma [1]. SGK1 confers resistance of breast cancer cells to chemotherapy $[3,10,56]$, and inhibition of SGK1 sensitizes tumor cells to cytotoxic drugs or radiation [12]. SGK1 contributes to androgen-induced growth of prostate cancer cells [2]. SGK1 counteracts the pro-apoptotic effect of membrane androgen receptors (MAR) [1] in colon carcinoma cells [57-59]. Lack of SGK1 blunts the development of spontaneous tumors in APC-deficient mice [2] and chemically-induced colonic tumors in wild-type mice [1].

SGK1 stimulates cell proliferation and inhibits cell death in part by up-regulating channels and transporters, such as the store-operated $\mathrm{Ca}^{2+}$ entry (SOCE) accomplished by ORAI1/STIM1 [1, 12, 34, 35, 60, 61]. SOCE maintains oscillations of cytosolic $\mathrm{Ca}^{2+}$ activity, which are required for depolymerization of the actin filament network, a prerequisite for cell proliferation $[3,10] . \mathrm{Ca}^{2+}$ entry is driven by the cell membrane potential, which is generated by SGK1 sensitive $\mathrm{K}^{+}$channels $[3,10]$. The protective effect of SGK1 on neurons similarly involves, at least in part, up-regulation of ORAI1/STIM1 [51].

SGK1 further inactivates the pro-apoptotic forkhead transcription factor FOXO3A/FKRHL1 [1], inhibits GSK-3 and up-regulates oncogenic $\beta$-catenin [3, 7], activates IKK $\beta$ with subsequent phosphorylation and degradation of the inhibitory protein IKB and translocation of NF-KB into the nucleus [10], activates the ubiquitin ligase MDM2 with subsequent MDM2-dependent ubiquitination and proteosomal degradation of pro-apoptotic transcription factor p53 [1], disrupts binding of SEK1 to JNK1 and MEKK1 $[3,10]$ and upregulates Ran binding protein (RanBP), an effect affecting microtubule network and blunting taxol sensitivity of cancer cells [52, 62].

\section{CELL MIGRATION}

SGK1 is part of the machinery stimulating cell migration [47, $57,58,63,64]$. As shown in vascular smooth muscle cells (VSMCs) [64], the stimulation of migration by plateletderived growth factor PDGF is paralleled by up-regulation of both, SGK1 expression and SGK1 activity $[65,66]$. Genetic knockout of SGK1 decreases migration [64]. SGK1 is effective, at least in part, by up-regulation of the store- operated $\mathrm{Ca}^{2+}$ entry (SOCE), which is accomplished by the $\mathrm{Ca}^{2+}$ channel ORAI1 and its regulator STIM1. Expression of ORAI1 and STIM1 is stimulated by NF-KB, a transcription factor up-regulated by SGK1 $[1,64]$. In VSMCs, SGK1 triggers nuclear translocation of transcription factor NF-KB [64].

\section{INFLAMMATION AND FIBROSIS}

SGK1 contributes to the orchestration of inflammation [52, 67-70]. The kinase is required for the interleukin-23 (IL-23)sensitive generation of interleukin-17 (IL-17)-producing $\mathrm{CD}^{+}$helper $\mathrm{T}$ cells ( $\mathrm{T}_{\mathrm{H}} 17$ cells) [71]. $\mathrm{T}_{\mathrm{H}} 17$ cells up-regulate the pro-inflammatory cytokines GM-CSF, TNF- $\alpha$ and interleukin-2 (IL-2) [71].

SGK1 further contributes to fibrosis in several clinical conditions, including lung fibrosis, diabetic nephropathy, glomerulonephritis, experimental nephrotic syndrome, obstructive nephropathy, cardiac remodeling, liver cirrhosis, fibrosing pancreatitis, peritoneal fibrosis, Crohn's disease and coeliac disease [1, 3, 72-75]. The expression of SGK1 is upregulated by TGF $\beta$ [3], a pivotal stimulator of fibrosis [69, 76-81]. Signaling of TGF $\beta$ includes activation of transcription factors SMAD2/3 [1], which are ubiquitinated and, thus, tagged for degradation by NEDD4L [1]. The ubiquitin ligase is inactivated by SGK1 which thus augments TGF $\beta$ action [1]. SGK1 supports inflammation and fibrosis further by activating NF-kB [3], a proinflammatory and profibrotic transcription factor $[1,82,83]$. NF-kB upregulates connective tissue growth factor (CTGF), which in turn contributes to stimulation of cardiac remodeling and fibrosis [1, 3, 84-87], renal proteinuria and failure [88], skin aging [15], as well as fibronectin formation at hyperglycemia [1].

\section{VASCULAR CALCIFICATION}

SGK1 further participates in the orchestration of medial vascular calcification [84], which results mainly from osteo/chondrogenic transdifferentiation of VSMCs [84]. Various triggers of VSMC osteo-/chondrogenic transdifferentiation induce a sharp increase of SGK1 expression [84]. Upregulation of SGK1 was also observed in the vasculature of rats with renal failure [89]. SGK1 increases the expression of the osteo-/chondrogenic transcription factors MSX2 and $C B F A 1$, which in turn stimulate the expression of alkaline phosphatase ALPL [84]. The enzyme fosters vascular calcification by degrading the endogenous calcification inhibitor pyrophosphate. The effect of SGK1 on osteo/chondrogenic transdifferentiation depends on transcriptional activity of NF-kB, a decisive regulator of vascular calcification [90, 91]. NF-KB also reduces pyrophosphate release via tristetraprolin (TTP)-mediated destabilization of ankylosis protein homolog (ANKH) mRNA $[90,91]$.

\section{THE ROLE OF SGK1 IN DISEASE - CLINICAL IMPLICATIONS}

A wide variety of observations point to a role of SGK1 in human pathophysiology [12]. Excessive expression and activity of SGK1 participates in the pathophysiology of di 


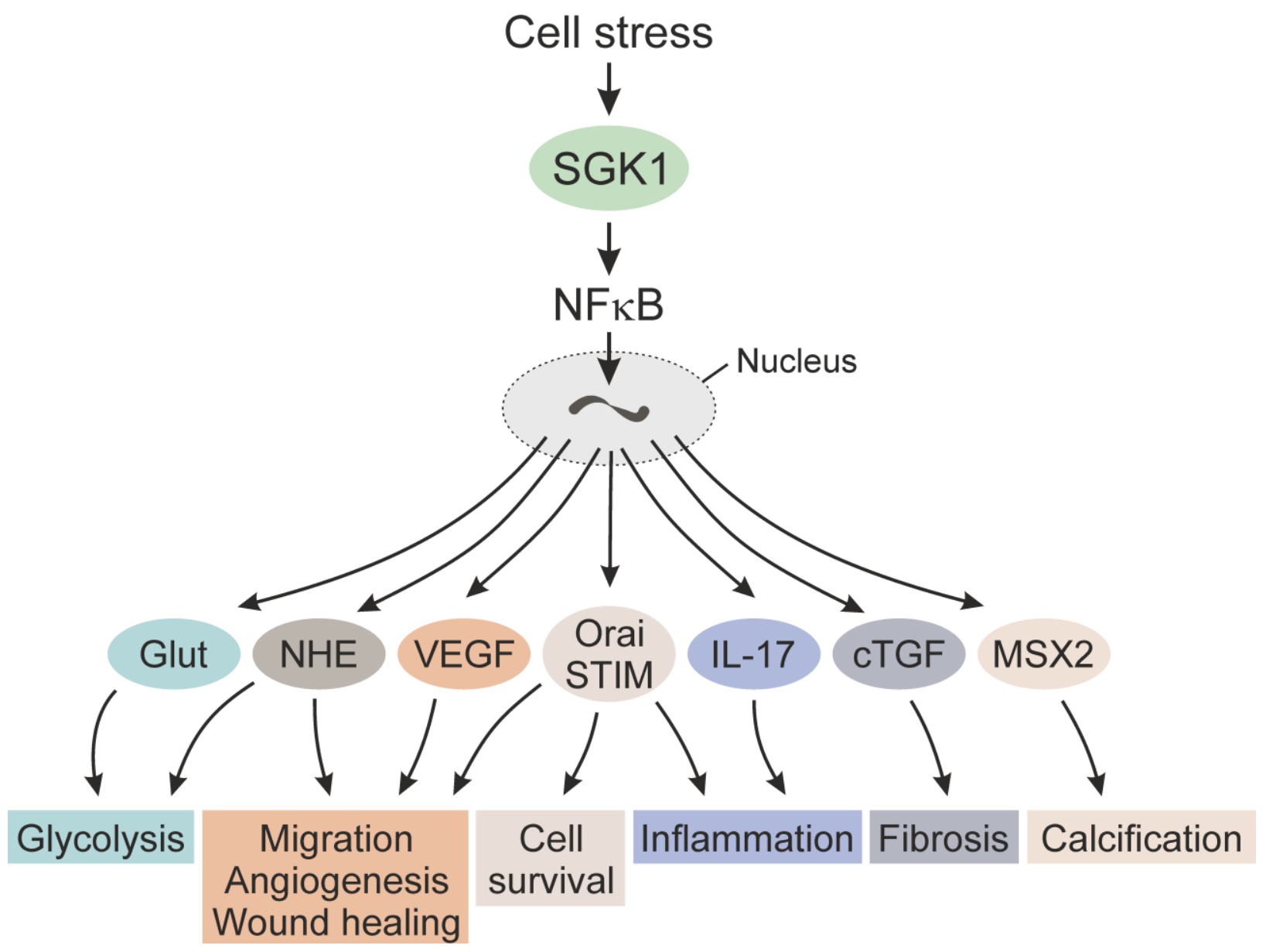

FIGURE 1: SGK1-sensitive NFKB-dependent transcription in the response to cell stress. Please note that additional NFKB-dependent genes as well as NFkB-independent mechanisms contribute to the cellular response to stress.

verse disorders, such as hypertension, obesity, diabetes, thrombosis, stroke, fibrosing disease, vascular calcification, infertility, autoimmune disease, and tumor growth $[12,71,84]$. A SGK1 gene variant (prevalence approx. 3-5\% in Caucasians and approx. $10 \%$ in Africans) is associated with hypertension, stroke, obesity and type 2 diabetes [12] Little is known about the clinical impact of SGK1 deficiency. In a SV129 genetic background, the phenotype of SGK1 knockout mice is mild and SGK1-dependent functions are apparently in large part maintained by other kinases [12]. In view of the putative role of SGK1 in neuronal survival [51], however, the possibility must be kept in mind that lack of SGK1 may accelerate the clinical course of neurodegeneration. Clearly, additional experimental and observational effort is required to define the pathophysiological impact of deranged SGK1 activity in human disease.

\section{CONCLUSIONS}

Expression of the serum- and glucocorticoid-inducible kinase SGK1 is steeply up-regulated following cell stress, such as ischemia, radiation and hyperosmotic shock. The SGK1 protein is activated by a signaling cascade involving phosphatidylinositide-3-kinase (PI3K), 3-phosphoinositidedependent kinase 1 (PDK1) and mTOR. SGK1 is a powerful stimulator of transport across the cell membrane, such as $\mathrm{Na}^{+} / \mathrm{K}^{+}$-ATPase, $\mathrm{Na}^{+} / \mathrm{H}^{+}$exchangers, cellular glucose uptake and ORAI1/STIM1-dependent store-operated $\mathrm{Ca}^{2+}$ entry (SOCE). SGK1 is further a powerful stimulator of transcription factors including nuclear factor KB (NF-KB; Figure 1). Upon cell stress such as energy depletion, SGK1 supports cellular glucose uptake and glycolysis, angiogenesis, cell survival, cell migration, and wound healing. If those functions fail to remove the cell stress, SGK1 initiates replacement of energy consuming cells by fibrotic and/or calcified tissue.

\section{ACKNOWLEDGMENTS}

The authors acknowledge the meticulous preparation of the manuscript by Lejla Subasic and the figure by Tanja Loch. Research in author's laboratories was supported by the Deutsche Forschungsgemeinschaft.

\section{CONFLICT OF INTEREST}

The authors declare that they have no conflict of interest.

\section{COPYRIGHT}

(C) 2019 Lang et al. This is an open-access article released under the terms of the Creative Commons Attribution (CC 
BY) license, which allows the unrestricted use, distribution, and reproduction in any medium, provided the original author and source are acknowledged.

\section{REFERENCES}

1. Lang F, Stournaras C (2013). Serum and glucocorticoid inducible kinase, metabolic syndrome, inflammation, and tumor growth. Hormones 12(2): 160-171. doi: 10.14310/horm.2002.1401

2. Lang F, Gorlach A, Vallon V (2009). Targeting SGK1 in diabetes. Expert Opin Ther Targets 13(11): 1303-1311. doi: $10.1517 / 14728220903260807$

3. Lang F, Bohmer C, Palmada M, Seebohm G, Strutz-Seebohm N, Vallon $V$ (2006). (Patho)physiological significance of the serum- and glucocorticoid-inducible kinase isoforms. Physiol Rev 86(4): 11511178. doi: 10.1152/physrev.00050.2005

4. Salker MS, Christian M, Steel JH, Nautiyal J, Lavery S, Trew G, Webster Z, Al-Sabbagh M, Puchchakayala G, Foller M, Landles C, Sharkey AM, Quenby S, Aplin JD, Regan L, Lang F, Brosens JJ (2011). Deregulation of the serum- and glucocorticoid-inducible kinase SGK1 in the endometrium causes reproductive failure. Nat Med 17(11): 15091513. doi: $10.1038 / \mathrm{nm} .2498$

5. Firestone GL, Giampaolo JR, O'Keeffe BA (2003). Stimulusdependent regulation of serum and glucocorticoid inducible protein kinase (SGK) transcription, subcellular localization and enzymatic activity. Cell Physiol Biochem 13(1): 1-12. doi: 10.1159/000070244

6. Waldegger S, Barth P, Raber G, Lang F (1997). Cloning and characterization of a putative human serine/threonine protein kinase transcriptionally modified during anisotonic and isotonic alterations of cell volume. Proc Natl Acad Sci U S A 94(9): 4440-4445. doi: 10.1073/pnas.94.9.4440

7. Lang F, Artunc F, Vallon V (2009). The physiological impact of the serum and glucocorticoid-inducible kinase SGK1. Curr Opin Nephro Hypertens 18(5): 439-448. doi: 10.1097/mnh.0b013e32832f125e

8. Lang F, Gorlach A (2010). Heterocyclic indazole derivatives as SGK1 inhibitors, WO2008138448. Expert Opin Ther Pat 20(1): 129-135. doi: $10.1517 / 13543770903365209$

9. Lang F, Huang DY, Vallon V (2010). SGK, renal function and hypertension. J Nephrol 23 (Suppl 16): S124-129. PMID: 21170869

10. Lang F, Perrotti N, Stournaras C (2010). Colorectal carcinoma cells-regulation of survival and growth by SGK1. Int J Biochem Cell Biol 42(10): 1571-1575. doi: 10.1016/j.biocel.2010.05.016

11. Lang F, Eylenstein A, Shumilina E (2012). Regulation of Orai1/STIM1 by the kinases SGK1 and AMPK. Cell Calcium 52(5): 347354. doi: 10.1016/j.ceca.2012.05.005

12. Lang F, Voelkl J (2013). Therapeutic potential of serum and glucocorticoid inducible kinase inhibition. Expert Opin Investig Drugs 22(6): 701-714. doi: 10.1517/13543784.2013.778971

13. Harries LW, Fellows AD, Pilling LC, Hernandez D, Singleton A Bandinelli S, Guralnik J, Powell J, Ferrucci L, Melzer D (2012). Advancing age is associated with gene expression changes resembling mTOR inhibition: evidence from two human populations. Mech Ageing Dev 133(8): 556-562. doi: 10.1016/j.mad.2012.07.003

14. PelzI L, Tolios A, Schmidt EM, Alesutan I, Walker B, Munzer P, Borst $O$, Gawaz M, Lang F (2012). Translational regulation of the serum- and glucocorticoid-inducible kinase-1 (SGK1) in platelets. Biochem Biophys Res Commun 425(1): 1-5. doi: 10.1016/j.bbrc.2012.07.026

15. Tsai V, Parker WE, Orlova KA, Baybis M, Chi AW, Berg BD, Birnbaum JF, Estevez J, Okochi K, Sarnat HB, Flores-Sarnat L, Aronica E,
Please cite this article as: Florian Lang, Christos Stournaras, Nefeli Zacharopoulou, Jakob Voelkl, Ioana Alesutan (2019). Serum- and glucocorticoid-inducible kinase 1 and the response to cell stress. Cell Stress 3(1): 1-8. doi: 10.15698/cst2019.01.170

Crino PB (2014). Fetal brain mTOR signaling activation in tuberous sclerosis complex. Cereb Cortex 24(2): 315-327. doi: 10.1093/cercor/bhs310

16. Dibble CC, Asara JM, Manning BD (2009). Characterization of Rictor phosphorylation sites reveals direct regulation of mTOR complex 2 by S6K1. Mol Cell Biol 29(21): 5657-5670. doi: 10.1128/mcb.00735-09

17. Fang Z, Zhang T, Dizeyi N, Chen S, Wang H, Swanson KD, Cai C, Balk SP, Yuan X (2012). Androgen Receptor Enhances p27 Degradation in Prostate Cancer Cells through Rapid and Selective TORC2 Activation. J Biol Chem 287(3): 2090-2098. doi: 10.1074/jbc.m111.323303

18. Hall BA, Kim TY, Skor MN, Conzen SD (2012). Serum and glucocor ticoid-regulated kinase 1 (SGK1) activation in breast cancer: requirement for mTORC1 activity associates with ER-alpha expression. Breast Cancer Res Treat 135(2): 469-479. doi: 10.1007/s10549-012-2161-y

19. Heise CJ, Xu BE, Deaton SL, Cha SK, Cheng CJ, Earnest S, Sengupta S, Juang YC, Stippec S, Xu Y, Zhao Y, Huang CL, Cobb MH (2010). Serum and glucocorticoid-induced kinase (SGK) 1 and the epithelial sodium channel are regulated by multiple with no lysine (WNK) family members. J Biol Chem 285(33): 25161-25167. doi 10.1074/jbc.m110.103432

20. Lyo D, Xu L, Foster DA (2010). Phospholipase D stabilizes HDM2 through an mTORC2/SGK1 pathway. Biochem Biophys Res Commun 396(2): 562-565. doi: 10.1016/j.bbrc.2010.04.148

21. Pearce LR, Sommer EM, Sakamoto K, Wullschleger S, Alessi DR (2011). Protor-1 is required for efficient $m$ TORC2-mediated activation of SGK1 in the kidney. Biochem J 436(1): 169-179. doi: 10.1042/bj20102103

22. Peterson TR, Laplante M, Thoreen CC, Sancak Y, Kang SA, Kueh WM, Gray NS, Sabatini DM (2009). DEPTOR is an mTOR inhibitor frequently overexpressed in multiple myeloma cells and required for their survival. Cell 137(5): 873-886. doi: 10.1016/j.cell.2009.03.046

23. Rosner M, Dolznig H, Fuchs C, Siegel N, Valli A, Hengstschlager M (2009). CDKs as therapeutic targets for the human genetic disease tuberous sclerosis? Eur J Clin Invest 39(12): 1033-1035. doi: 10.1111/j.1365-2362.2009.02213.x

24. Treins C, Warne PH, Magnuson MA, Pende M, Downward J (2010) Rictor is a novel target of p70 S6 kinase-1. Oncogene 29:1003-1016. doi: 10.1038/onc.2009.401

25. Thomanetz V, Angliker $\mathrm{N}$, Cloetta $\mathrm{D}$, Lustenberger RM, Schweighauser M, Oliveri F, Suzuki N, Ruegg MA (2013). Ablation of the mTORC2 component rictor in brain or Purkinje cells affects size and neuron morphology. J Cell Biol 201(2): 293-308. doi: 10.1083/jcb.201205030

26. Domhan S, Schwager C, Wei Q, Muschal S, Sommerer C, Morath C, Wick W, Maercker C, Debus J, Zeier M, Huber PE, Abdollahi A (2014). Deciphering the systems biology of mTOR inhibition by integrative transcriptome analysis. Curr Pharm Des 20(1): 88-100. doi: 10.2174/138161282001140113125549

27. Na T, Wu G, Zhang W, Dong WJ, Peng JB (2013). Disease-causing $\mathrm{R} 1185 \mathrm{C}$ mutation of WNK4 disrupts a regulatory mechanism involving calmodulin binding and SGK1 phosphorylation sites. Am J Physiol Renal Physiol 304(1): F8-F18. doi: 10.1152/ajprenal.00284.2012 
28. Lee SM, Lee YJ, Yoon JJ, Kang DG, Lee HS (2012). Effect of Poria cocos on hypertonic stress-induced water channel expression and apoptosis in renal collecting duct cells. J Ethnopharmacol 141(1): 368 376. doi: 10.1016/j.jep.2012.02.048

29. Gao D, Wan L, Inuzuka H, Berg AH, Tseng A, Zhai B, Shaik S, Bennett E, Tron AE, Gasser JA, Lau A, Gygi SP, Harper JW, DeCaprio JA, Toker A, Wei W (2010). Rictor forms a complex with Cullin-1 to promote SGK1 ubiquitination and destruction. Mol Cell 39(5): 797-808. doi: $10.1016 /$ j.molcel.2010.08.016

30. Gao D, Wan L, Wei W (2010). Phosphorylation of Rictor at Thr1135 impairs the Rictor/Cullin-1 complex to ubiquitinate SGK1. Protein Cell 1(10): 881-885. doi: 10.1007/s13238-010-0123-x

31. Renauld S, Tremblay K, Ait-Benichou S, Simoneau-Roy M, Garneau $\mathrm{H}$, Staub O, Chraibi A (2010). Stimulation of ENaC activity by rosiglitazone is PPARgamma-dependent and correlates with SGK1 expression increase. J Membr Biol 236(3): 259-270. doi: 10.1007/s00232-010 9297-7

32. Soundararajan R, Wang J, Melters D, Pearce D (2010). Glucocorticoid-induced Leucine zipper 1 stimulates the epithelial sodium channel by regulating serum- and glucocorticoid-induced kinase 1 stability and subcellular localization. J Biol Chem 285(51): 39905-39913. doi: $10.1074 / j b c . m 110.161133$

33. Park J, Leong ML, Buse $P$, Maiyar AC, Firestone GL, Hemmings BA (1999). Serum and glucocorticoid-inducible kinase (SGK) is a target of the PI 3-kinase-stimulated signaling pathway. EMBO J 18(11): 30243033. doi: 10.1093/emboj/18.11.3024

34. Borst O, Schmidt EM, Munzer P, Schonberger T, Towhid ST, Elvers M, Leibrock C, Schmid E, Eylenstein A, Kuhl D, May AE, Gawaz M, Lang $F$ (2012). The serum- and glucocorticoid-inducible kinase 1 (SGK1) influences platelet calcium signaling and function by regulation of Orai1 expression in megakaryocytes. Blood 119(1): 251-261. doi: 10.1182/blood-2011-06-359976

35. Eylenstein A, Schmidt S, Gu S, Yang W, Schmid E, Schmidt EM, Alesutan I, Szteyn K, Regel I, Shumilina E, Lang F (2012). Transcription factor NF-kappaB regulates expression of pore-forming Ca2+ channel unit, Orai1, and its activator, STIM1, to control Ca2+ entry and affect cellular functions. J Biol Chem 287(4): 2719-2730. doi: 10.1074/jbc.m111.275925

36. Rotte A, Pasham V, Eichenmuller M, Yang W, Bhandaru M, Lang F (2011). Influence of dexamethasone on $n+/ h+$ exchanger activity in dendritic cells. Cell Physiol Biochem 28(2): 305-314. doi: 10.1159/000331746

37. Terada $Y$, Kuwana $H$, Kobayashi $T$, Okado $T$, Suzuki N, Yoshimoto $T$, Hirata Y, Sasaki S (2008). Aldosterone-stimulated SGK1 activity mediates profibrotic signaling in the mesangium. J Am Soc Nephrol 19(2): 298-309. doi: 10.1681/asn.2007050531

38. Murakami Y, Hosoi F, Izumi H, Maruyama $Y$, Ureshino $H$, Watari $\mathrm{K}$, Kohno K, Kuwano M, Ono M (2010). Identification of sites subjected to serine/threonine phosphorylation by SGK1 affecting N-myc downstream-regulated gene 1 (NDRG1)/Cap43-dependent suppression of angiogenic CXC chemokine expression in human pancreatic cancer cells. Biochem Biophys Res Commun 396(2): 376-381. doi: 10.1016/j.bbrc.2010.04.100

39. Dehner M, Hadjihannas M, Weiske J, Huber O, Behrens J (2008). Wnt signaling inhibits Forkhead box O3a-induced transcription and apoptosis through up-regulation of serum- and glucocorticoidinducible kinase 1. J Biol Chem 283(28): 19201-19210. doi: $10.1074 / j b c . m 710366200$

40. Sahin P, McCaig C, Jeevahan J, Murray JT, Hainsworth AH (2013). The cell survival kinase SGK1 and its targets FOXO3a and NDRG1 in aged human brain. Neuropathol Appl Neurobiol 39(6): 623-633. doi: 10.1111/nan.12023
41. Lang F, Shumilina E (2013). Regulation of ion channels by the serum- and glucocorticoid-inducible kinase SGK1. FASEB J 27(1): 3-12. doi: 10.1096/fj.12-218230

42. McCaig C, Potter L, Abramczyk O, Murray JT (2011). Phosphorylation of NDRG1 is temporally and spatially controlled during the cell cycle. Biochem Biophys Res Commun 411(2): 227-234. doi: 10.1016/j.bbrc.2011.06.092

43. Ohashi T, Uchida K, Uchida S, Sasaki S, Nitta K (2011). Dexamethasone increases the phosphorylation of nephrin in cultured podocytes. Clin Exp Nephrol 15(5): 688-693. doi: 10.1007/s10157-0110479-0

44. Voelkl J, Castor T, Musculus K, Viereck R, Mia S, Feger M, Alesutan I, Lang F (2015). SGK1-Sensitive Regulation of Cyclin-Dependent Kinase Inhibitor 1B (p27) in Cardiomyocyte Hypertrophy. Cell Physiol Biochem 37(2): 603-614. doi: 10.1159/000430380

45. Rusai K, Prokai A, Szebeni B, Fekete A, Treszl A, Vannay A, Muller V, Reusz G, Heemann U, Lutz J, Tulassay T, Szabo AJ (2010). Role of serum and glucocorticoid-regulated kinase-1 in the protective effects of erythropoietin during renal ischemia/reperfusion injury. Biochem Pharmacol 79(8): 1173-1181. doi: 10.1016/j.bcp.2009.11.022

46. Catela C, Kratsios P, Hede M, Lang F, Rosenthal N (2010). Serum and glucocorticoid-inducible kinase 1 (SGK1) is necessary for vascular remodeling during angiogenesis. Dev Dyn 239(8): 2149-2160. doi: $10.1002 / d v d y .22345$

47. Zarrinpashneh E, Poggioli T, Sarathchandra $P$, Lexow J, Monassier L, Terracciano C, Lang F, Damilano F, Zhou JQ, Rosenzweig A, Rosenthal N, Santini MP (2013). Ablation of SGK1 impairs endothelial cell migration and tube formation leading to decreased neo-angiogenesis following myocardial infarction. PLoS One 8(11): e80268. doi: 10.1371/journal.pone.0080268

48. Chen L, Wei TQ, Wang Y, Zhang J, Li H, Wang KJ (2012). Simulated bladder pressure stimulates human bladder smooth muscle cell proliferation via the PI3K/SGK1 signaling pathway. J Urol 188(2): 661-667. doi: 10.1016/j.juro.2012.03.112

49. Towhid ST, Liu GL, Ackermann TF, Beier N, Scholz W, Fuchss T, Toulany M, Rodemann HP, Lang F (2013). Inhibition of colonic tumor growth by the selective SGK inhibitor EMD638683. Cell Physiol Biochem 32(4): 838-848. doi: 10.1159/000354486

50. Baskin R, Sayeski PP (2012). Angiotensin II mediates cell survival through upregulation and activation of the serum and glucocorticoid inducible kinase 1. Cell Signal 24(2): 435-442. doi: 10.1016/j.cellsig.2011.09.016

51. Pelzl L, Hauser S, Elsir B, Sukkar B, Sahu I, Singh $Y$, Hoflinger $P$ Bissinger R, Jemaa M, Stournaras C, Schols L, Lang F (2017). Lithium Sensitive ORAl1 Expression, Store Operated $\mathrm{Ca}(2+)$ Entry and Suicidal Death of Neurons in Chorea-Acanthocytosis. Sci Rep 7(1): 6457. doi: 10.1038/s41598-017-06451-1

52. Lang F, Guelinckx I, Lemetais G, Melander O (2017). Two Liters a Day Keep the Doctor Away? Considerations on the Pathophysiology of Suboptimal Fluid Intake in the Common Population. Kidney Blood Press Res 42(3): 483-494. doi: 10.1159/000479640

53. Abbruzzese C, Mattarocci S, Pizzuti L, Mileo AM, Visca P, Antoniani $B$, Alessandrini G, Facciolo F, Amato R, D'Antona L, Rinaldi M, Felsani A, Perrotti N, Paggi MG (2012). Determination of SGK1 mRNA in nonsmall cell lung cancer samples underlines high expression in squamous cell carcinomas. J Exp Clin Cancer Res 31(1): 4. doi: 10.1186/17569966-31-4

54. Szmulewitz RZ, Chung E, Al-Ahmadie H, Daniel S, Kocherginsky M, Razmaria A, Zagaja GP, Brendler CB, Stadler WM, Conzen SD (2012). Serum/glucocorticoid-regulated kinase 1 expression in primary human prostate cancers. Prostate 72(2): 157-164. doi: 10.1002/pros.21416 
55. Fagerli UM, Ullrich K, Stuhmer T, Holien T, Kochert K, Holt RU, Bruland O, Chatterjee M, Nogai H, Lenz G, Shaughnessy JD, Jr., Mathas S, Sundan A, Bargou RC, Dorken B, Borset M, Janz M (2011). Serum/glucocorticoid-regulated kinase 1 (SGK1) is a prominent target gene of the transcriptional response to cytokines in multiple myeloma and supports the growth of myeloma cells. Oncogene 30(28): 3198 3206. doi: 10.1038/onc.2011.79

56. Sommer EM, Dry H, Cross D, Guichard S, Davies BR, Alessi DR (2013). Elevated SGK1 predicts resistance of breast cancer cells to Akt inhibitors. Biochem J 452(3): 499-508. doi: 10.1042/bj20130342

57. Schmidt EM, Kraemer BF, Borst $O$, Munzer $P$, Schonberger $T$, Schmidt C, Leibrock C, Towhid ST, Seizer P, Kuhl D, Stournaras C, Lindemann S, Gawaz M, Lang F (2012). SGK1 sensitivity of platelet migration. Cell Physiol Biochem 30(1): 259-268. doi: 10.1159/000339062

58. Schmidt EM, Gu S, Anagnostopoulou V, Alevizopoulos K, Foller M, Lang F, Stournaras C (2012). Serum- and glucocorticoid-dependent kinase-1-induced cell migration is dependent on vinculin and regulated by the membrane androgen receptor. FEBS J 279(7): 1231-1242. doi: 10.1111/j.1742-4658.2012.08515.x

59. Gu S, Papadopoulou N, Nasir O, Foller M, Alevizopoulos K, Lang F, Stournaras $C$ (2011). Activation of membrane androgen receptors in colon cancer inhibits the prosurvival signals Akt/bad in vitro and in vivo and blocks migration via vinculin/actin signaling. Mol Med 17(12): 48-58. doi: 10.2119/molmed.2010.00120

60. Eylenstein A, Gehring EM, Heise N, Shumilina E, Schmidt S, Szteyn K, Munzer P, Nurbaeva MK, Eichenmuller M, Tyan L, Regel I, Foller M, Kuhl D, Soboloff J, Penner R, Lang F (2011). Stimulation of Ca2+channel Orai1/STIM1 by serum- and glucocorticoid-inducible kinase 1 (SGK1). FASEB J 25(6): 2012-2021. doi: 10.1096/fj.10-178210

61. Schmidt S, Schneider S, Yang W, Liu G, Schmidt EM, Schmid E, Mia S, Brucker S, Stournaras C, Wallwiener D, Brosens JJ, Lang F (2014). TGFbeta1 and SGK1-sensitive store-operated Ca2+ entry and Orai1 expression in endometrial Ishikawa cells. Mol Hum Reprod 20(2): 139147. doi: $10.1093 /$ molehr/gat066

62. Amato R, Scumaci D, D'Antona L, Iuliano R, Menniti M, Di Sanzo M Faniello MC, Colao E, Malatesta P, Zingone A, Agosti V, Costanzo FS, Mileo AM, Paggi MG, Lang F, Cuda G, Lavia P, Perrotti N (2013). Sgk1 enhances RANBP1 transcript levels and decreases taxol sensitivity in RKO colon carcinoma cells. Oncogene 32(38): 4572-4578. doi: 10.1038/onc. 2012.470

63. Liu T, Yu T, Hu H, He K (2018). Knockdown of the long non-coding RNA HOTTIP inhibits colorectal cancer cell proliferation and migration and induces apoptosis by targeting SGK1. Biomed Pharmacother 98 286-296. doi: 10.1016/j.biopha.2017.12.064

64. Walker-Allgaier B, Schaub M, Alesutan I, VoelkI J, Geue S, Munzer P, Rodriguez JM, Kuhl D, Lang F, Gawaz M, Borst O (2017). SGK1 upregulates Orai1 expression and VSMC migration during neointima formation after arterial injury. Thromb Haemost 117(5): 1002-1005. doi: 10.1160/th16-09-0690

65. Caglayan E, Vantler M, Leppanen O, Gerhardt F, Mustafov L, Ten Freyhaus $\mathrm{H}$, Kappert K, Odenthal M, Zimmermann WH, Tallquist MD, Rosenkranz S (2011). Disruption of platelet-derived growth factordependent phosphatidylinositol 3-kinase and phospholipase Cgamma 1 activity abolishes vascular smooth muscle cell proliferation and migration and attenuates neointima formation in vivo. J Am Coll Cardiol 57(25): 2527-2538. doi: 10.1016/j.jacc.2011.02.037

66. Zhong W, Oguljahan B, Xiao Y, Nelson J, Hernandez L, Garcia-Barrio $M$, Francis SC (2014). Serum and glucocorticoid-regulated kinase 1 promotes vascular smooth muscle cell proliferation via regulation of beta-catenin dynamics. Cell Signal 26(12): 2765-2772. doi 10.1016/j.cellsig.2014.08.002
67. Lang F, Stournaras C, Alesutan I (2014). Regulation of transport across cell membranes by the serum- and glucocorticoid-inducible kinase SGK1. Mol Membr Biol 31(1): 29-36. doi 10.3109/09687688.2013.874598

68. Waldegger S, Klingel K, Barth P, Sauter M, Rfer ML, Kandolf R, Lang $F$ (1999). h-sgk serine-threonine protein kinase gene as transcriptional target of transforming growth factor beta in human intestine. Gastroenterology 116(5): 1081-1088. doi: 10.1016/s0016-5085(99)70011-9

69. Szebeni B, Vannay A, Sziksz E, Prokai A, Cseh A, Veres G, Dezsofi A Gyorffy H, Szabo IR, Arato A (2010). Increased expression of serumand glucocorticoid-regulated kinase-1 in the duodenal mucosa of children with coeliac disease. J Pediatr Gastroenterol Nutr 50(2): 147153. doi: 10.1097/mpg.0b013e3181b47608

70. Binger KJ, Gebhardt $M$, Heinig $M$, Rintisch $C$, Schroeder A, Neuhofer W, Hilgers K, Manzel A, Schwartz C, Kleinewietfeld M, Voelkl J, Schatz V, Linker RA, Lang F, Voehringer D, Wright MD, Hubner N, Dechend R, Jantsch J, Titze J, Muller DN (2015). High salt reduces the activation of IL-4- and IL-13-stimulated macrophages. J Clin Invest 125(11): 4223-4238. doi: 10.1172/jci80919

71. Kleinewietfeld M, Manzel A, Titze J, Kvakan H, Yosef N, Linker RA Muller DN, Hafler DA (2013). Sodium chloride drives autoimmune disease by the induction of pathogenic TH17 cells. Nature 496(7446): 518-522. doi: 10.1038/nature11868

72. Cheng J, Truong LD, Wu X, Kuhl D, Lang F, Du J (2010). Serum- and glucocorticoid-regulated kinase 1 is upregulated following unilateral ureteral obstruction causing epithelial-mesenchymal transition. Kidney Int 78(7): 668-678. doi: 10.1038/ki.2010.214

73. Akhurst RJ, Hata A (2012). Targeting the TGFbeta signalling pathway in disease. Nat Rev Drug Discov 11(10): 790-811. doi: $10.1038 / \mathrm{nrd} 3810$

74. Bezzerides VJ, Zhang A, Xiao L, Simonson B, Khedkar SA, Baba S, Ottaviano F, Lynch S, Hessler K, Rigby AC, Milan D, Das S, Rosenzweig A (2017). Inhibition of serum and glucocorticoid regulated kinase-1 as novel therapy for cardiac arrhythmia disorders. Sci Rep 7(1): 346. doi: 10.1038/s41598-017-00413-3

75. Voelkl J, Pasham V, Ahmed MS, Walker B, Szteyn K, Kuhl D, Metzler B, Alesutan I, Lang F (2013). Sgk1-dependent stimulation of cardiac $\mathrm{Na}+\mathrm{H}+$ exchanger Nhe1 by dexamethasone. Cell Physiol Biochem 32(1): 25-38. doi: 10.1159/000350120

76. Hong $Y$, Cao H, Wang Q, Ye J, Sui L, Feng J, Cai X, Song H, Zhang X, Chen X (2016). MiR-22 may Suppress Fibrogenesis by Targeting TGFbetaR I in Cardiac Fibroblasts. Cell Physiol Biochem 40(6): 1345-1353. doi: 10.1159/000453187

77. Guo Y, Dong Z, Shi Y, Wang W, Wang L, Sun J, Sun X, Tian Z, Yao J, Li Z, Cheng J, Tian Y (2016). Sonodynamic Therapy Inhibits Fibrogene sis in Rat Cardiac Fibroblasts Induced by TGF-beta1. Cell Physiol Biochem 40(3-4): 579-588. 10.1159/000452571

78. Yu F, Yang J, Huang K, Pan X, Chen B, Dong P, Zheng J (2016). The Epigenetically-Regulated microRNA-378a Targets TGF-beta2 in TGFbeta1-Treated Hepatic Stellate Cells. Cell Physiol Biochem 40(1-2): 183-194. doi: 10.1159/000452536

79. Li X, Han D, Tian Z, Gao B, Fan M, Li C, Li X, Wang Y, Ma S, Cao F (2016). Activation of Cannabinoid Receptor Type II by AM1241 Ameliorates Myocardial Fibrosis via Nrf2-Mediated Inhibition of TGF beta1/Smad3 Pathway in Myocardial Infarction Mice. Cell Physiol Biochem 39(4): 1521-1536. doi: 10.1159/000447855

80. Zhang F, Dang Y, Li Y, Hao Q, Li R, Qi X (2016). Cardiac Contractility Modulation Attenuate Myocardial Fibrosis by Inhibiting TGFbeta1/Smad3 Signaling Pathway in a Rabbit Model of Chronic Heart Failure. Cell Physiol Biochem 39(1): 294-302. doi: 10.1159/000445624 
81. Feger M, Alesutan I, Castor T, Mia S, Musculus K, Voelkl J, Lang F (2015). Inhibitory effect of $\mathrm{NH} 4 \mathrm{Cl}$ treatment on renal Tgfss1 signaling following unilateral ureteral obstruction. Cell Physiol Biochem 37(3): 955-964. doi: 10.1159/000430222

82. Shih VF, Tsui R, Caldwell A, Hoffmann A (2011). A single NFkappaB system for both canonical and non-canonical signaling. Cell Res 21(1): 86-102. doi: 10.1038/cr.2010.161

83. Stone KP, Kastin AJ, Pan W (2011). NFkB is an unexpected major mediator of interleukin-15 signaling in cerebral endothelia. Cell Physiol Biochem 28(1): 115-124. doi: 10.1159/000331720

84. Chilukoti RK, Mostertz J, Bukowska A, Aderkast C, Felix SB, Busch M, Volker U, Goette A, Wolke C, Homuth G, Lendeckel U (2013). Effects of irbesartan on gene expression revealed by transcriptome analysis of left atrial tissue in a porcine model of acute rapid pacing in vivo. Int J Cardiol 168(3): 2100-2108. doi: 10.1016/j.ijcard.2013.01.007

85. Yang M, Zheng J, Miao Y, Wang Y, Cui W, Guo J, Qiu S, Han Y, Jia L, Li H, Cheng J, Du J (2012). Serum-glucocorticoid regulated kinase 1 regulates alternatively activated macrophage polarization contributing to angiotensin II-induced inflammation and cardiac fibrosis. Arterioscler Thromb Vasc Biol 32(7): 1675-1686. doi: 10.1161/atvbaha.112.248732

86. Das S, Aiba T, Rosenberg M, Hessler K, Xiao C, Quintero PA, Ottaviano FG, Knight AC, Graham EL, Bostrom P, Morissette MR, del Monte F, Begley MJ, Cantley LC, Ellinor PT, Tomaselli GF, Rosenzweig A (2012). Pathological role of serum- and glucocorticoid-regulated kinase 1 in adverse ventricular remodeling. Circulation 126(18): 22082219. doi: 10.1161/circulationaha.112.115592
87. Voelkl J, Lin Y, Alesutan I, Ahmed MS, Pasham V, Mia S, Gu S, Feger M, Saxena A, Metzler B, Kuhl D, Pichler BJ, Lang F (2012). Sgk1 sensitivity of $\mathrm{Na}(+) / \mathrm{H}(+)$ exchanger activity and cardiac remodeling following pressure overload. Basic Res Cardiol 107(2): 236. doi: 10.1007/s00395-011-0236-2

88. Artunc F, Amann K, Nasir O, Friedrich B, Sandulache D, Jahovic N, Risler T, Vallon V, Wulff P, Kuhl D, Lang F (2006). Blunted DOCA/high salt induced albuminuria and renal tubulointerstitial damage in genetargeted mice lacking SGK1. J Mol Med 84(9): 737-746. doi: 10.1007/s00109-006-0082-0

89. Tatsumoto N, Yamada S, Tokumoto M, Eriguchi M, Noguchi $H$, Torisu K, Tsuruya K, Kitazono T (2015). Spironolactone ameliorates arterial medial calcification in uremic rats: the role of mineralocorticoid receptor signaling in vascular calcification. Am J Physiol Renal Physiol 309(11): F967-979. doi: 10.1152/ajprenal.00669.2014

90. Voelkl J, Tuffaha R, Luong TTD, Zickler D, Masyout J, Feger M, Verheyen N, Blaschke F, Kuro OM, Tomaschitz A, Pilz S, Pasch A, Eck ardt KU, Scherberich JE, Lang F, Pieske B, Alesutan I (2018). Zinc Inhibits Phosphate-Induced Vascular Calcification through TNFAIP3Mediated Suppression of NF-kappaB. J Am Soc Nephrol 29(6): 16361648. doi: 10.1681/asn.2017050492

91. Zhao G, Xu MJ, Zhao MM, Dai XY, Kong W, Wilson GM, Guan Y, Wang CY, Wang $X$ (2012). Activation of nuclear factor-kappa B accelerates vascular calcification by inhibiting ankylosis protein homolog expression. Kidney Int 82(1): 34-44. doi: 10.1038/ki.2012.40 